\title{
USING MULTIVARIATE STATISTICAL TECHNIQUES AND ESTIMATION OF SOME GENETIC PARAMETERS IN THIRTEEN FABA BEAN GENOTYPES
}

(Received:12.12.2014)

\author{
By \\ E. M. Rabie and H. E.A. Ibrahim* \\ Field crops Research Institute, * Central Laboratory For Design and Statistical \\ Analysis Research, Agriculture Research Center, Giza, Egypt
}

\begin{abstract}
Two field experiments were conducted at the Agricultural Research Station of gemmeiza, ARC, ElGharbia Governorate during 2011/2012 and 2012/2013 seasons in order to evaluate the performance of thirteen Faba bean genotypes for seed yield per plant and its related characters. Four statistical procedures, i.e. correlation and multiple regression analysis, factor and cluster analysis were applied to determine the main contributing characters in seed weight per plant variation. Genotype 2 possessed the earliest flowering plants and Genotype 9 (mutant 1) possessed the earliest matured plants. Genotype 8 followed by Genotype, 6, 4 and 1 showed the tallest plants, highest number of pods, seeds, seeds yield per plant and 100 seed weight. Highly significant and positive associations were obtained between seed weight/plant and each of number of seeds/plant and number of pods/plant. The full model regression gave R-square of 0.995 , which means that $99.5 \%$ of the variation in Faba bean yield is explained by the independent variables in the model. Step-wise regression analysis for seed yield / plant as dependent variable and the other traits as independent, revealed that number of seeds, 100seed weight and number of branches are the most important seed yield / plant components. These traits accounted for $99.26 \%$ of total variation exist in seed yield / plant. Factorial analysis classified the eight studied characters, as yield per plant components, into three main factors explained $79.49 \%$ of the total variability in the dependent structure. Factor 1 was responsible for $35.71 \%$ of the total variation and included number of pods/plant, number of seeds/plant and seeds yield /plant. Factor 2 included100seed weight, days to maturity and plant height contributed by $24.49 \%$ of the total variation. Number of branches/plant and days to flowering accounted for $19.29 \%$ of the total variation. Graphically, showing eigen values in response to number of components for the estimated variables of Faba bean. The hierarchical cluster analysis permitted the classification of the genotypes according to similarity groups. Analysis of variance for traits studied showed significant differences among the genotypes. Phenotypic coefficient of variation for most characters was closer to the corresponding genotypic coefficient of variation values, showing little environmental effect on the expression of these characters. The highest values of phenotypic and genotypic coefficients of variation were obtained with number of branches/plant, seeds yield/ plant, number of seed and number of pods/plant indicating a wide range of variation which provided a good opportunity for yield improvement. Also, large proportions of heritability coupled with high values of genetic advance (\% of mean) were recorded for the number of branches/plant, seeds yield/ plant, number of seeds and the number of pods/plant, explaining that these traits have more chance for Faba bean yield development among the tested genotypes.
\end{abstract}

Key words: Faba bean, genetic parameters, multivariate statistical analysis.

\section{INTRODUCTION}

Faba bean, broad bean or field bean (Vicia $f a b a$ L.) is a major legume that is used as food owing to the high nutrient components in seeds (Duc, 1997). It is largely consumed in the Middle East. Genetic variability of Faba bean is quite large. Vicia faba is a considerable source of energy: $344 \mathrm{~K} \mathrm{cal} / 100 \mathrm{~g}$ and can efficiently replace animal protein in poor countries (Bond et al., 1985 and Duke, 1981). It is a significant source of protein rich food in developing countries. It is also used both as a human food and a feed, horses, poultry and pigeons in industrialized countries (Duke, 1981). Its 
characteristics are suitable for sustainable agriculture (Nadal et al., 2003). Faba bean is also grown for green manure and can significantly enhance yields of cereals or other crops (Wani et al., 1994). Several studies were concentrated about the impact of each yield component on the yield.

The main goal when growing crops everywhere is to maximize net profit mainly through increasing seed yield. Different types of multivariate analysis such as factor and cluster analysis can be used to identify groups of genotypes that have beneficial traits for breeding and instructing the patterns of variation in genotype accession, to recognize relationships among accessions and possible gaps (Cowen and Frey, 1987). Though simple correlation coefficient is very useful in quantifying the size
The objectives of this work were to study the genetic parameters and identify the interrelationships among seed yield and its related characters using correlation and regression analysis and cluster and factor analysis. The results may be helpful to plan appropriate selection strategies for improving seed yield in Faba bean.

\section{MATERIALS AND METHODS}

\subsection{Location of the study and plant materials}

The present study was carried out at the Agricultural Research Station of Gemmeiza (ARC) to evaluate the performance of 13 Faba bean genotypes (crosses resulted from F7) for yield and its related characters. The details of pedigree for the tested genotypes are presented in Table (1).

Table (1): Name and pedigree of the studied faba bean genotypes.

\begin{tabular}{|c|c|c|}
\hline $\begin{array}{l}\text { Genotype } \\
\text { number }\end{array}$ & $\begin{array}{l}\text { Genotype } \\
\text { name }\end{array}$ & Pedigree \\
\hline 1 & Cross 1 & Giza $461 \times$ Gizablanka \\
\hline 2 & Cross 2 & T.W. $\times$ Gizablanka \\
\hline 3 & Cross 3 & Giza $716 \times$ Giza 402 \\
\hline 4 & Cross 4 & Giza $461 \times$ Giza 402 \\
\hline 5 & Cross 5 & $($ Gizablanka $\times$ Giza 2$) \times$ misr 1 \\
\hline 6 & Cross 6 & $($ Giza $429 \times$ Giza 2$) \times$ misr 1 \\
\hline 7 & Cross 7 & $($ Gizablanka $\times$ Giza 40) $\times$ misr 1 \\
\hline 8 & Cross 8 & Giza $461 \times$ Giza 3 \\
\hline 9 & Mutant1 & Giza $461 \mathrm{M}$ \\
\hline 10 & Cross 9 & $($ TripleWhite $\times$ Giza429) $\times$ Misr 1 \\
\hline 11 & Giza 834 & $561 / 2076 / 85 \times 461 / 845 / 83$ \\
\hline 12 & Misr 1 & Derived from $G 3 \times 123 \mathrm{~A} / 45 / 76$ \\
\hline 13 & Giza 3 & Cross (Giza 1× Dutch) \\
\hline
\end{tabular}

and direction of association, it may not always be effective because it provides only one dimensional coefficient neglecting important and complex interrelationships among other traits (Kang, 1994).

The factor analysis is also a data reduction method to reduce the number of variables into factors. Cluster analysis is a multivariate method for grouping the individuals or objects according to their traits, and classifying the individuals with similar types into the same group or cluster (Hair et al., 1995). Chaieb et al. (2011) used the hierarchical cluster analysis for classification of 14 Faba bean genotypes according to some morphological traits. Sarparast et al. (2011) used cluster analysis to investigate genotypic structure of nine Faba bean genotypes.

\subsection{Experimental design and plot arrangement}

The experiments were designed in a Randomized Complete Blocks Design (RCBD) with three replications. Each replicate consisted of thirteen plots, each devoted to one genotype. Plots were $11.2 \mathrm{~m}^{2}$ including four ridges, $2.8 \mathrm{~m}$ long spaced $0.7 \mathrm{~m}$ apart, in hills spaced $0.2 \mathrm{~m}$ apart. The two season experiments were sown on $15^{\text {th }}$ and $20^{\text {th }}$ of November for 2011/2012 and 2012/2013 seasons respectively. All the recommended cultural practices were followed up to harvest and all agronomic practices were carried out uniformly for all treatments.

\subsubsection{Data collection}

Data on different agronomic traits were collected on both plant and plot basis. 
At maturity ten plants were taken at random from the inner two ridges in each plot to measure the following traits: days to $50 \%$ flowering, days to maturity, plant height $(\mathrm{cm})$, number of branches per plant, number of pods per plant, number of seeds per plant, 100-seed weight (g) and seed yield per plant $(\mathrm{g})$.

\subsection{Statistical analysis and estimation of genetic parameters}

Individual analysis of variance was performed for all the studied traits on each season according to the procedure described by Snedecor and Cochran (1989) for a randomized complete blocks design with three replications. The combined data across the two seasons were subjected to statistical analysis using MSTAT- C computer software. Data for the two years were tested for homogeneity error variance using Ftest and it was found to be homogeneous so the data were combined for analysis. Least significant differences LSD test at 5\% level of probability was used to compare means.

Four statistical procedures, differing in mathematical background, goals and final output, were used to explore the relationships between seed yield/plant and other traits of Faba bean. The used models are summarized as follows:

Simple correlation coefficients were computed among seed yield/plant and its components (Gomez and Gomez, 1984).

Multiple regression analysis according to Draper and Smith, (1966) was done to develop equations to predict yield.

Factor analysis: This approach was applied according to Cattell (1965) to reduce a large number of correlated variables to a much smaller number of independent clusters of variables called factors. After the loading of the first factor was calculated, the process was repeated on the residual matrix to find further factors. When the contribution of a factor to the total percentage of the trace was less than $10 \%$, the process was stopped. After extraction, the matrix of factor loadings was submitted to a Varimax Orthogonal Rotation, as applied by Kaiser (1958). The purpose of rotation was to rebuild the larger loadings in each factor and to suppress the minor loading coefficient so as to improve the opportunity of achieving meaningful biological interpretation of each factor.

Cluster Analysis (CA) was used to arrange a set of variables into clusters. The aim was to establish a set of clusters so that cases within a cluster are more similar to each other than between clusters. This description may be abstracted through the use of the particular to the general class or type (Polignano et al., 1989). Twin span (two way indicator species analysis) was used to classify variables producing an order two way table of their occurrence. The cluster analysis was performed using a measure of similarity levels and Euclidean distance (Everitt, 1993 and Eisen et al., 1998).

The genotypic and phenotypic variances $\left(\sigma_{\mathrm{g}}^{2}\right.$ and $\sigma_{\mathrm{ph}}^{2}$ ) were calculated from the results of analysis of variance as follows:

1- Genotypic variance $\left(\sigma_{g}^{2}\right)$ was calculated from the formula outlined by

Comstok and Moll (1963):

$\sigma_{g}^{2}=(\mathrm{Mg}-\mathrm{Msg}) / \mathrm{rs}$

Where $\sigma_{g}^{2}=$ Genotypic variance

$\mathrm{Mg}=$ Mean square of genotypes

Msg = Mean square of the seasons $\mathrm{x}$ genotypes interaction.

$\mathrm{r}=$ Number of replications.

$\mathrm{s}=$ Number of environments (seasons).

2- Phenotypic variance $\left(\sigma_{\mathrm{ph}}^{2}\right)$ was computed according to the following equation as applied by Mathur et al. (1971) and Verma and Singh (1971):

$\sigma_{\mathrm{ph}}^{2}=\sigma_{\mathrm{g}}^{2}+\left(\sigma_{\mathrm{sg}}^{2} / \mathrm{r}\right)+\left(\sigma_{\mathrm{e}}^{2} / \mathrm{rs}\right)$

Where $\sigma_{\text {sg }}^{2}=(\mathrm{Msg}-\mathrm{Me}) / \mathrm{r}$.

$\sigma_{\mathrm{e}}^{2}=\mathrm{Me}$ (error mean square).

Genotypic and phenotypic coefficients of variation were calculated according to Burton (1951) as follows:

G. C. V. $=\sigma_{\mathrm{g}} / \overline{\times} .100$ and P. C. V. $=\sigma_{\mathrm{ph}} / \overline{\times} .100$. Broad sense heritability $(\mathrm{H})$ was calculated as described by Hanson (1963) using the following formula:

$\mathrm{h}_{\mathrm{b}} \%=\left(\sigma_{\mathrm{g}}^{2} / \sigma_{\mathrm{ph}}^{2}\right) .100$

The expected genetic advance under selection (Gs) was calculated from the following formula as suggested by Fehr (1987):

$\mathrm{Gs}=\mathrm{K} \cdot \sigma_{\mathrm{ph}} \cdot \mathrm{h}_{\mathrm{b}}$

Where $\sigma_{\mathrm{ph}}=$ The phenotypic standard deviation and

$\mathrm{K}=$ The selection differential in standard deviation units. In this investigation, the value used for $\mathrm{K}$ is 2.06, which corresponds to selecting the best $5 \%$ of the population.

\section{RESULTS AND DISCUSSION}

\subsection{Combined analysis of variance}

The results of combined analysis of variance after homogeneity test for error variances are summarized in Table (2). F-test of different sources of variation revealed that there were no significant differences of the year effects for all 
traits except for plant height, while the effect of genotypes was significant for all traits except for plant height. cross 8 possessed the highest values for the number of pods and seeds per plant and recorded (27.50) and (79.57 g), respectively. On the other hand, cross 6 possessed the least values for the

Table (2): Combined analysis of variance of the evaluated genotypes over two seasons.

\begin{tabular}{|l|c|c|c|c|c|c|c|c|c|}
\hline \multicolumn{10}{|c|}{ Mean squares } \\
\hline SOV & df & $\begin{array}{c}\text { Days to } \\
\mathbf{5 0 \%} \\
\text { Flowering }\end{array}$ & $\begin{array}{c}\text { Days } \\
\text { to } \\
\text { Maturity }\end{array}$ & $\begin{array}{c}\text { Plant } \\
\text { height } \\
\text { (cm) }\end{array}$ & $\begin{array}{c}\text { Number } \\
\text { of } \\
\text { branches/ } \\
\text { plant }\end{array}$ & $\begin{array}{c}\text { Number } \\
\text { of } \\
\text { pods/plant }\end{array}$ & $\begin{array}{c}\text { Number of } \\
\text { seeds/plant }\end{array}$ & $\begin{array}{c}\text { Seed yield } \\
\text { /plant (g) }\end{array}$ & $\begin{array}{c}\text { 100-seed } \\
\text { weight } \\
\text { (g) }\end{array}$ \\
\hline Rep & $\mathbf{2}$ & $\mathbf{5 . 3 5}$ & $\mathbf{8 . 1 7}$ & $\mathbf{3 . 0 1}$ & $\mathbf{0 . 2 9}$ & $\mathbf{3 . 9 5}$ & $\mathbf{2 9 . 7 9}$ & $\mathbf{2 4 . 9 4}$ & $\mathbf{0 . 2 8 9}$ \\
\hline Genotypes & $\mathbf{1 2}$ & $\mathbf{2 1 . 7 2 * *}$ & $\mathbf{1 4 . 6 0}$ & $\mathbf{5 3 . 4 5}$ & $\mathbf{7 . 7 8}$ & $\mathbf{3 1 . 2 7}$ & $\mathbf{3 8 6 . 6 5}$ & $\mathbf{2 5 4 . 4 6}$ & $\mathbf{8 4 . 8 9}$ \\
\hline Error & $\mathbf{2 4}$ & $\mathbf{1 . 2 6}$ & $\mathbf{1 . 3 5}$ & $\mathbf{2 8 . 2 2}$ & $\mathbf{0 . 3 7}$ & $\mathbf{3 . 6 2}$ & $\mathbf{2 5 . 7 9}$ & $\mathbf{1 2 . 1 4}$ & $\mathbf{2 . 6 1}$ \\
\hline
\end{tabular}

\subsection{Mean performance}

The mean performances of thirteen Faba bean genotypes for different traits are given in Table (3). Based on two year data; results revealed that the cross 2 possessed the earliest flowering plants (47.33 days) and matured after157.17 days. On the other hand, the cultivar Giza 3 took 53.33 and 156.33 days to flower and maturity, respectively.

With respect to maturity date, M1 possessed the earliest matured plants (153.33 days). On the other hand, cross 5 possessed the latest ones (158.00 days). Regarding to plant height, Cross 6 possessed the tallest plants $(103.17 \mathrm{~cm})$ whereas, Cross 9 exhibited the shortest plants $(94.17 \mathrm{~cm})$. For the number of branches per plant, cross 2 showed the profuse plants (5.63) whereas the cultivar Giza 3 possessed the lowest branched plants (2.23). Results showed that the number of pods (19.05) and the number of seeds per plant (50.23). For seed yield per plant and 100-seed weight, cross 1 possessed the heaviest seed weight (60.57 and $84.75 \mathrm{~g}$ ) among the thirteen genotypes. On the other hand, cross 5 possessed the lowest value of 100 seed weight (72.80 g), and cross 6 possessed the lowest value of seed yield per plant $(41.1 \mathrm{~g})$

According to the previous results, it could be concluded that the tallest plants, highest number of pods, seed yield per plant and 100 seed weight were obtained by cross 8 followed by cross 6 , cross 4 and cross 1 . These results reflect that the selection prospects within this genotype to improve the performance through breeding program.

These results are in harmony with those reported by Bastawisy et al. (2006), Salem (2011) and Ihsanullh (2010) who found

Table (3): Mean performance of 13 faba bean genotypes for the studied traits (Combined data over two years).

\begin{tabular}{|c|c|c|c|c|c|c|c|c|}
\hline Genotype & $\begin{array}{c}\text { Days to } \\
\mathbf{5 0 \%} \\
\text { Flowering }\end{array}$ & $\begin{array}{c}\text { Days to } \\
\text { Maturity }\end{array}$ & $\begin{array}{c}\text { Plant } \\
\text { height } \\
(\mathbf{c m})\end{array}$ & $\begin{array}{c}\text { Number of } \\
\text { branches/plant }\end{array}$ & $\begin{array}{c}\text { Number } \\
\text { of } \\
\text { pods/plant }\end{array}$ & $\begin{array}{c}\text { Number of } \\
\text { seeds/plant }\end{array}$ & $\begin{array}{c}\text { Seed } \\
\text { yield } \\
\text { /plant (g) }\end{array}$ & $\begin{array}{c}100- \\
\text { seed } \\
\text { weight } \\
\text { (g) }\end{array}$ \\
\hline Cross 1 & $\mathbf{5 2 . 0 0}$ & $\mathbf{1 5 7 . 1 7}$ & $\mathbf{9 9 . 6 7}$ & $\mathbf{5 . 5 0}$ & $\mathbf{2 4 . 4 7}$ & $\mathbf{7 1 . 6 0}$ & $\mathbf{6 0 . 5 7}$ & $\mathbf{8 4 . 7 5}$ \\
\hline Cross 2 & $\mathbf{4 7 . 3 3}$ & $\mathbf{1 5 7 . 1 7}$ & $\mathbf{9 7 . 3 3}$ & $\mathbf{5 . 6 3}$ & $\mathbf{2 3 . 3 3}$ & $\mathbf{6 2 . 7 8}$ & $\mathbf{4 8 . 7 5}$ & $\mathbf{7 7 . 8 5}$ \\
\hline Cross 3 & $\mathbf{5 1 . 0 0}$ & $\mathbf{1 5 5 . 8 3}$ & $\mathbf{9 6 . 6 7}$ & $\mathbf{5 . 5 0}$ & $\mathbf{2 4 . 2 8}$ & $\mathbf{6 8 . 7 5}$ & $\mathbf{5 2 . 5 0}$ & $\mathbf{7 6 . 4 8}$ \\
\hline Cross 4 & $\mathbf{5 0 . 5 0}$ & $\mathbf{1 5 7 . 3 3}$ & $\mathbf{1 0 2 . 5 0}$ & $\mathbf{4 . 2 0}$ & $\mathbf{2 1 . 6 5}$ & $\mathbf{6 1 . 7 8}$ & $\mathbf{5 1 . 1 5}$ & $\mathbf{8 2 . 9 2}$ \\
\hline Cross 5 & $\mathbf{5 0 . 5 0}$ & $\mathbf{1 5 8 . 0 0}$ & $\mathbf{9 8 . 0 0}$ & $\mathbf{4 . 9 8}$ & $\mathbf{2 4 . 6 0}$ & $\mathbf{6 7 . 0 7}$ & $\mathbf{4 8 . 7 8}$ & $\mathbf{7 2 . 8 0}$ \\
\hline Cross 6 & $\mathbf{5 1 . 0 0}$ & $\mathbf{1 5 7 . 8 3}$ & $\mathbf{1 0 3 . 1 7}$ & $\mathbf{4 . 6 3}$ & $\mathbf{1 9 . 0 5}$ & $\mathbf{5 0 . 2 3}$ & $\mathbf{4 1 . 1 0}$ & $\mathbf{8 0 . 3 7}$ \\
\hline Cross 7 & $\mathbf{4 8 . 3 3}$ & $\mathbf{1 5 5 . 1 7}$ & $\mathbf{1 0 2 . 5 0}$ & $\mathbf{3 . 9 8}$ & $\mathbf{1 9 . 3 2}$ & $\mathbf{5 2 . 7 3}$ & $\mathbf{3 9 . 2 0}$ & $\mathbf{7 4 . 4 0}$ \\
\hline Cross 8 & $\mathbf{5 2 . 8 3}$ & $\mathbf{1 5 6 . 0 0}$ & $\mathbf{1 0 2 . 1 7}$ & $\mathbf{3 . 8 5}$ & $\mathbf{2 7 . 5 0}$ & $\mathbf{7 9 . 5 7}$ & $\mathbf{5 9 . 9 7}$ & $\mathbf{7 5 . 4 7}$ \\
\hline M1 & $\mathbf{4 7 . 8 3}$ & $\mathbf{1 5 3 . 3 3}$ & $\mathbf{9 7 . 1 7}$ & $\mathbf{4 . 6 5}$ & $\mathbf{2 3 . 6 7}$ & $\mathbf{5 7 . 1 3}$ & $\mathbf{4 6 . 1 5}$ & $\mathbf{8 0 . 7 3}$ \\
\hline Cross 9 & $\mathbf{5 2 . 3 3}$ & $\mathbf{1 5 4 . 1 7}$ & $\mathbf{9 4 . 1 7}$ & $\mathbf{5 . 2 5}$ & $\mathbf{2 1 . 3 3}$ & $\mathbf{5 6 . 8 3}$ & $\mathbf{4 1 . 9 3}$ & $\mathbf{7 3 . 8 5}$ \\
\hline Giza 843 & $\mathbf{5 2 . 0 0}$ & $\mathbf{1 5 4 . 3 3}$ & $\mathbf{9 7 . 3 3}$ & $\mathbf{2 . 9 7}$ & $\mathbf{2 0 . 5 7}$ & $\mathbf{5 9 . 2 2}$ & $\mathbf{4 4 . 6 0}$ & $\mathbf{7 5 . 4 2}$ \\
\hline Misr 1 & $\mathbf{5 0 . 0 0}$ & $\mathbf{1 5 4 . 1 7}$ & $\mathbf{9 6 . 1 7}$ & $\mathbf{2 . 5 3}$ & $\mathbf{2 3 . 4 0}$ & $\mathbf{6 5 . 7 3}$ & $\mathbf{4 8 . 4 5}$ & $\mathbf{7 3 . 7 3}$ \\
\hline Giza 3 & $\mathbf{5 3 . 3 3}$ & $\mathbf{1 5 6 . 3 3}$ & $\mathbf{1 0 1 . 8 3}$ & $\mathbf{2 . 2 3}$ & $\mathbf{2 1 . 5 3}$ & $\mathbf{5 9 . 7 0}$ & $\mathbf{4 6 . 6 0}$ & $\mathbf{7 8 . 1 3}$ \\
\hline L. S. D 0.05 & $\mathbf{2 . 6 9}$ & $\mathbf{2 . 8 9}$ & NS & $\mathbf{1 . 5 2}$ & $\mathbf{2 . 9 3}$ & $\mathbf{6 . 6 9}$ & $\mathbf{6 . 1 9}$ & $\mathbf{4 . 1 8}$ \\
\hline
\end{tabular}


significant differences among tested genotypes for seed yield and its related characters.

\subsection{Correlation analysis}

The simple correlation coefficients among seed yield/plant and the other related traits are presented in Table (4). Results showed that all traits are associated highly significantly with seed yield/plant. The most important positive relationships to Faba bean breeder are those between seed yield/plant and each of the number of seeds/plant $\left(\mathrm{r}=0.924^{* *}\right)$ and the number of pods/plant $(\mathrm{r}=0.801 * *)$.

On the other hand, the traits of yield components exhibited considerable trends of associations among them. Positive and highly significant correlations were detected between seed yield/plant and each of the number of pods/plant $(\mathrm{r}=0.801 * *)$ and the number of seeds/plant $\left(\mathrm{r}=0.924^{* *}\right)$. Also, significant positive correlation $\left(\mathrm{r}=0.267^{*}\right)$ was observed between the number of pods/plant and the number of branches. The number of days to $50 \%$ flowering was found to be significantly and negatively associated with the number of

\subsection{Multiple linear regression analysis}

The obtained results showed that the prediction equation for seed yield per plant $(\hat{Y})$ is formulated using the Faba bean variables as follows:

Seed yield per plant $(\hat{Y})=-49.2+0.0119$ Plant height +0.100 Number of branches +0.0311 Flowering date - 0.0141 Maturity date, days 0.0266 Number of pods +0.765 Number of seeds $^{* *}+0.637$ weight of 100 -seed ${ }^{* *}$

$$
\mathrm{R}-\mathrm{Sq}=99.3 \% \quad \mathrm{R}-\mathrm{Sq}(\operatorname{adj})=99.2 \%
$$

The seed yield per plant formula explains $99.3 \%$ of the total variation within the yield components, while the remaining $0.7 \%$ may be due to residual effects. The t-test showed that number of seeds and weight of 100-seed has contributed significantly towards seed yield per plant. While the other six variables did not. The overall results reflect the importance of the mentioned commensurate two variables in Faba bean selection for breeding programs. These findings are in accordance with the results obtained by Chaieb et al. (2011).

Table (4): Simple correlation coefficients among the eight studied traits (combined over two seasons).

\begin{tabular}{|l|c|c|c|c|c|c|c|c|}
\hline Traits & Ph & NB & DF & DM & NP & NS & 100 SW & SY/P \\
\hline Ph & 1 & & & & & & & \\
\hline NB & 0.084 & 1 & & & & & & \\
\hline DF & -0.089 & $-0.278^{*}$ & 1 & & & & & \\
\hline DM & 0.155 & 0.191 & 0.106 & 1 & & & & \\
\hline NP & -0.046 & $0.267^{*}$ & 0.036 & -0.06 & 1 & & & \\
\hline NS & -0.127 & 0.156 & 0.212 & 0.059 & $0.872^{* *}$ & 1 & & \\
\hline 100SW & 0.180 & 0.095 & -0.084 & 0.270 & -0.153 & -0.164 & 1 & \\
\hline SY/P & -0.045 & 0.204 & 0.181 & 0.162 & $0.801^{* *}$ & $0.924^{* *}$ & 0.215 & 1 \\
\hline
\end{tabular}

*, ** and ns indicates significant at the 0.05 and 0.01 level of probability and insignificant, respectively. Ph: Plant height (cm), NB: No. of branches/plant, DF: Days to 50\% flowering, DM: Days to maturity, NP: No. of pods/plant, NS: No. of seeds/plant,100 SW:100 - seed weight (g) and SY/P: Seed yield/plant (g)

branches $\left(\mathrm{r}=-0.278^{*}\right)$. Similar results were observed by Hakan et al. (2003), Nawar et al. (2010), Talal and Shataya (2013) and Tafere et al. (2013).

\subsection{Stepwise multiple linear regression analysis}

Data presented in Table (5) show stepwise multiple regression analysis of the estimated

Table (5): Stepwise regression between seed yield per plant and some studied characters in Faba bean.

\begin{tabular}{|c|c|c|c|}
\hline Step & 1 & 2 & 3 \\
\hline Constant & 3.854 & -48.905 & -48.866 \\
\hline No. of seeds/plant & $\mathbf{0 . 7 1 3 0}$ & $\mathbf{0 . 7 6 0 6}$ & $\mathbf{0 . 7 5 8 6} * *$ \\
\hline 100 - seed weight $(\mathbf{g})$ & & $\mathbf{0 . 6 4 3}$ & $\mathbf{0 . 6 3 9} * *$ \\
\hline R-Sq & $\mathbf{8 5 . 4 1}$ & $\mathbf{9 9 . 2 4}$ & $\mathbf{9 9 . 2 6}$ \\
\hline R-Sq(adj) & $\mathbf{8 5 . 2 2}$ & $\mathbf{9 9 . 2 2}$ & $\mathbf{9 9 . 2 3}$ \\
\hline
\end{tabular}


variables in predicting seed yield per plant. The obtained results showed that $99.26 \%$ of the total variation in yield resulted from the number of seeds and 100 seed weight, as being the most suitable inputs to the model.

The obtained results showed that the best prediction equation for seed yield/plant $(\hat{Y})$ is formulated as follows:

Seed yield / plant $=-48.866+0.7586^{* *}$ number of seeds $+0.639^{* *}$ weight of 100 -seed.

Hence, it could be concluded that selection based on the number of seeds and 100 seed weight is more appropriate. These findings are in accordance with the results obtained by Golparvar (2012) and Mojgan et al. (2013),

\subsection{Factor analysis}

The factor analysis technique divided the eight studied Faba bean yield components into three independent groups or factors which explained $79.49 \%$ of the total variability in the dependence structure. The factors were constructed by applying the principal component approach to establish the dependent relationship between seed yield attributes in Faba bean. For interpretation only factor loadings greater than 0.5 were considered important (Seiler and Stafford, 1985). Summary of the composition of variables of the three extracted factors with loadings are given in Table (6) and Fig. (1). of the relationship between the factor and its related traits. It accounted for $24.49 \%$ of the total variability in the dependence structure.

Factor 3 was responsible for $19.29 \%$ of the total variability in the dependence structure. It included the two characters the number of branches/plant and days to $50 \%$ flowering. It contains the variable usually regarded as a growth and earliness factor. These results are in agreement with Mehasen and Mohamed (2004).

EL-Badawy (2006) found that using of factor analysis by plant breeders has the potential of increasing the comprehension of the casual relationship of variables and can help to determine the nature and sequence of traits to be selected in a breeding program.

\subsection{Cluster analysis}

Cluster analysis seemed to be an efficient procedure for extracting the structured relationships among accessions and provides a hierarchical classification of them (Polignano et al., 1989). Hierarchical cluster analysis for clustering the investigated 13 genotypes (the three categories) obtained with the average linkage procedure; UPGMA (un-weighted pair group method using arithmetic average) developed by Sokal and Michener (1958) is illustrated in Table (7) and Fig. (2).

Table (6): Summary of factor loadings for eight characters of Faba bean.

\begin{tabular}{|c|c|c|c|c|}
\hline Variable & Loading & \% Communality & Eigen values & $\%$ of variance \\
\hline Factor 1: & & & \multirow{4}{*}{2.856} & \multirow{5}{*}{35.71} \\
\hline No. of pods/plant & 0.924 & 0.884 & & \\
\hline No. of seeds/plant Seed & 0.935 & 0.955 & & \\
\hline yield/plant (g) & 0.950 & 0.970 & & \\
\hline Factor 2: & & & \multirow{4}{*}{1.959} & \\
\hline 100 - seed weight (g) & 0.716 & 0.568 & & \multirow{3}{*}{24.49} \\
\hline Days to maturity & 0.809 & 0.689 & & \\
\hline Plant height(cm) & 0.808 & 0.828 & & \\
\hline Factor 3: & & & \multirow{3}{*}{1.544} & \multirow{3}{*}{19.29} \\
\hline No. of branches/plant & 0.862 & 0.840 & & \\
\hline Days to $50 \%$ flowering & 0.698 & 0.625 & & \\
\hline Cumulative variance & & & & 79.49 \\
\hline
\end{tabular}

Factor 1 included three variables which accounted for $35.71 \%$ of the total variability. The three variables were the number of pods/plant, the number of seeds/plant and seed yield per plant. The three variables had high communality with factor 1 . Therefore, this factor may be called seed yield factor.

Factor 2 was made up of the traits100-seed weight, days to maturity and plant height. The sign of the loading values indicates the direction
The clustering pattern revealed that the genetic divergences in 13 genotypes on ten characters were grouped in 3 main clusters (Table 7). The maximum number of genotypes (7) was grouped in cluster 2 followed by cluster 3 (4) and cluster 1 (2).Thus, in view of considerable genetic diversity in Faba bean found in the present study, their appearance had sufficient scope for genotypic improvement through hybridization between the divergent 
Scree Plot

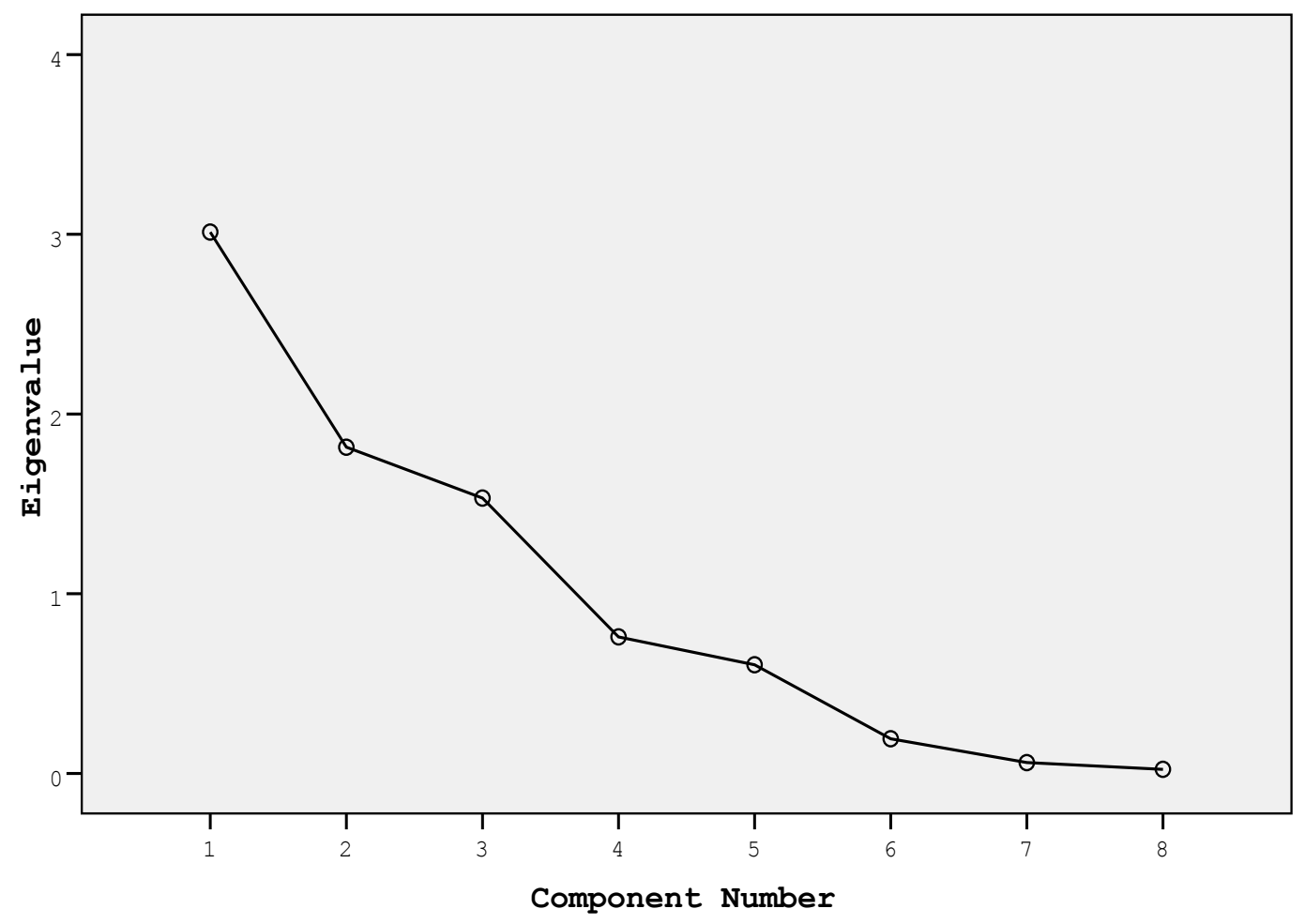

Fig. (1): Scree plot showing eigen values in response to the number of components for the estimated variables of Faba bean.

Table (7): Level of different clusters for faba bean studied genotypes(combined data over two years).

\begin{tabular}{|c|c|c|l|}
\hline Similarity & Cluster & No. of genotypes & genotypes included \\
\hline 62.56 & 1 & 2 & Cross1, Cross 8 \\
\hline 55.89 & 2 & 7 & Cross 2, M1, Cross 4, Giza 3, Cross 3, Cross5, Misr 1 \\
\hline 44.73 & 3 & 4 & Cross 6, Cross7, Cross9,Giza 483 \\
\hline
\end{tabular}




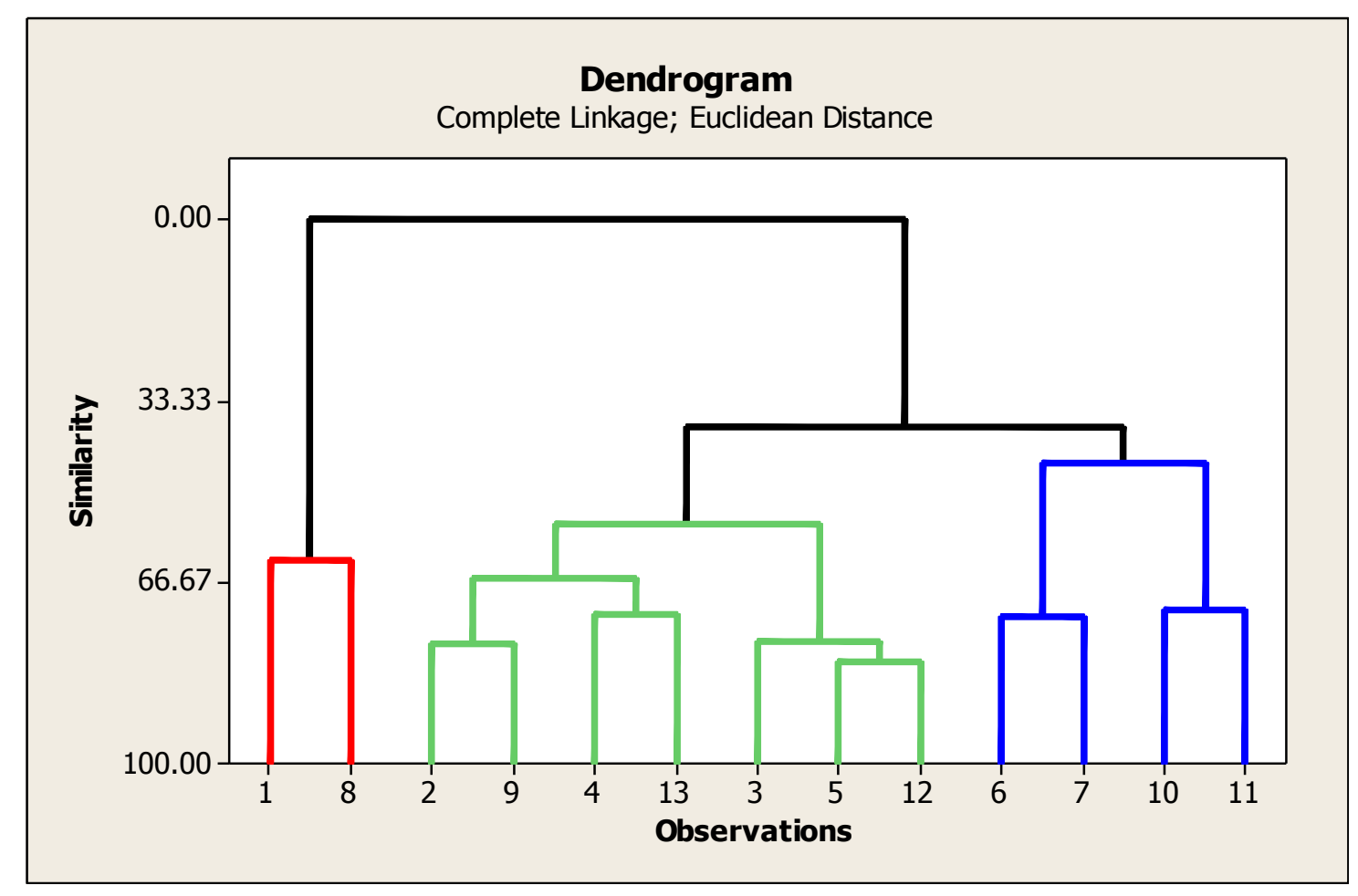

Fig. (2): Distribution of thirteen Faba bean genotypes in three clusters

$1=$ Cross $1,2=$ Cross $2,3=$ Cross $3,4=\operatorname{Cross} 4,5=\operatorname{Cross} 5,6=\operatorname{Cross} 6,7=\operatorname{Cross} 7,8=\operatorname{Cross} 8,9=$ M110 $=$ Cross 9, 11= Giza 843, $12=$ misr1, 13= Giza 3

genotypes (Eisen et al., 1998), Chaieb et al., 2011, Sarparast et al. (2011), Golparvar, 2012 and Peyman and Aminpana, (2014). The present investigation will be effective to assess the extent of available variability, which will be useful for selecting superior genotypes on the basis of their phenotypic expression so as to use them in breeding programs to improve the important characters.

\subsection{Variability and genetic parameters}

Genotypic and phenotypic coefficients of variation (GCV and PCV), broad sense of heritability $\left(h^{2}\right)$, and genetic advance expressed as percentage of the mean for the studied traits are shown in Table (8) and Fig. (3).

Because the variance as a measure of variability (phenotypic or genotypic) is affected by the measure unit of traits, it is seldom to be used in comparisons. Accordingly, the comparison among yield traits concerning the degree of variability was made using the magnitude of coefficient of variation which is an absolute measure of variability.

The estimate of (GCV) was only high for the number of branches/plant (36.26) while moderate values of (GCV) were recorded with seed yield/plant (19.09), No. of seeds/plant (16.35), number of pods/plant (14.01), 100-seed weight $(\mathrm{g})(6.60)$ and days to $50 \%$ flowering (5.10). The remaining two traits showed low estimates of (GCV).

On the other hand, the values of (PCV) were slightly higher than the values of (GCV) for all traits which reflect somewhat the influence of environment on the expression of traits. In accordance, the selection would be effective to improve these traits among the studied genotypes. Similar findings were reported by Mehasen and Mohamed (2004) and Tafere et al. (2013).

It is important to emphasize that, without considering genetic advance, the heritability values $\left(\mathrm{h}^{2}\right)$ would not be practically important in selection based on phenotypic appearance. Johnson et al., (1955) confirmed that heritability estimates along with genetic advance would give a more reliable index of selection value.

In the present investigation, high values of heritability coupled with high values of genetic advance (as \% of mean) were recorded for seed 
Table (8): Means, genotypic (GCV) and phenotypic (PCV) coefficients of variability, heritability $\left(\mathrm{h}^{2} \mathrm{bs}\right)$ and genetic advance (GA).

\begin{tabular}{|c|c|c|c|c|c|c|}
\hline Character & Mean & GCV \% & PCV \% & $h^{2} b$ & $\begin{array}{c}\text { Genetic } \\
\text { advance } \\
\text { (GA) }\end{array}$ & $\begin{array}{l}\text { Expected } \\
\text { GA(\% of } \\
\text { mean })\end{array}$ \\
\hline Plant height $(\mathrm{cm})$ & 99.13 & 3.73 & 4.19 & 79.27 & 6.78 & 6.84 \\
\hline No. of branches/plant & 4.31 & 36.26 & 36.75 & 97.34 & 3.18 & 73.69 \\
\hline Days to $50 \%$ flowering & 50.69 & 5.10 & 5.15 & 98.17 & 5.28 & 10.14 \\
\hline Days to maturity & 155.91 & 1.30 & 1.32 & 96.66 & 4.10 & 2.63 \\
\hline No. of pods/plant & 22.73 & 14.01 & 14.36 & 95.14 & 6.40 & 28.14 \\
\hline No. of seeds/plant & 69.17 & 16.35 & 16.55 & 97.57 & 23.01 & 33.27 \\
\hline 100 - seed weight (g) & $\mathbf{7 7 . 4 5}$ & 6.60 & 6.63 & 99.10 & 10.48 & 13.53 \\
\hline Seed yield/plant (g) & 48.44 & 19.09 & 19.26 & 98.18 & 18.87 & 38.96 \\
\hline
\end{tabular}

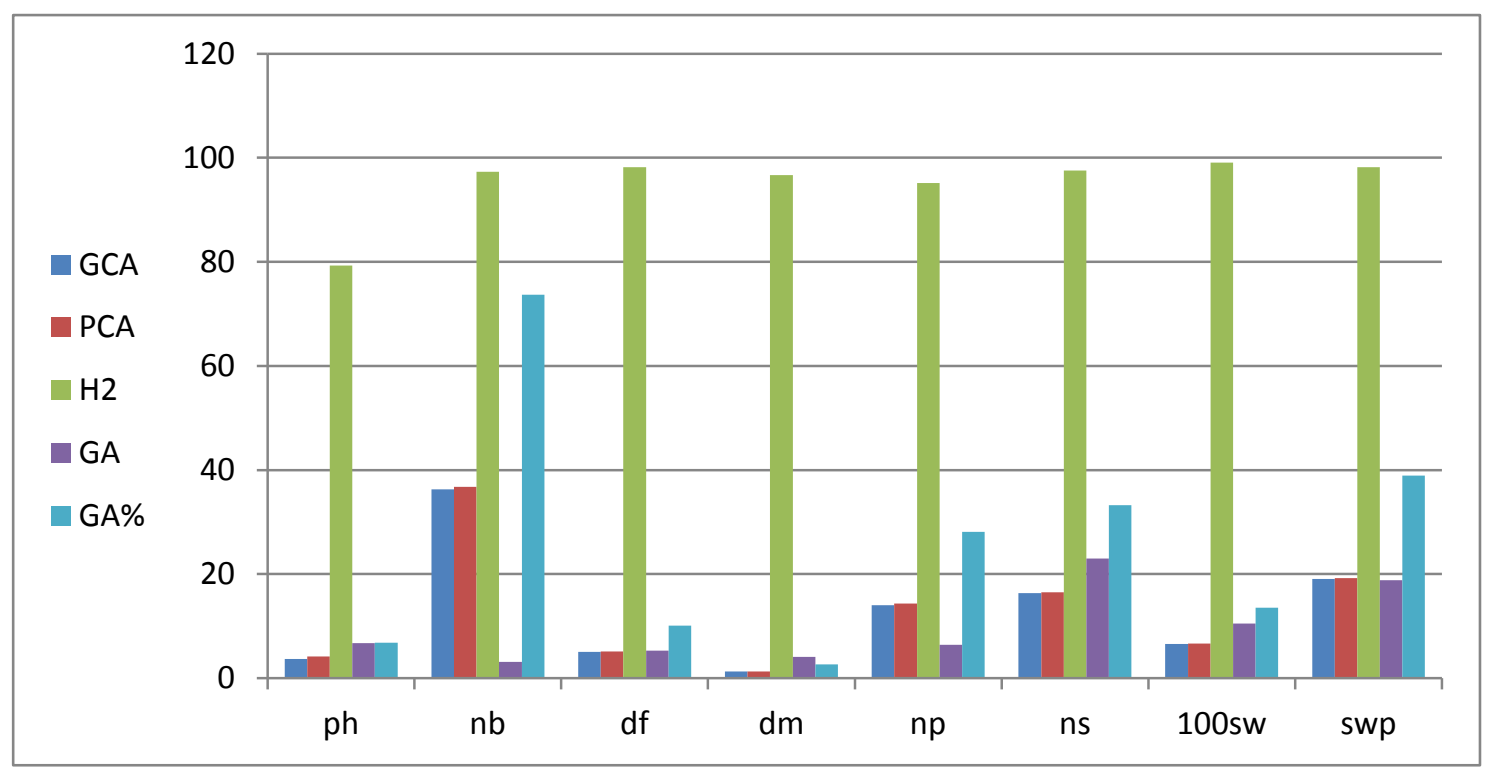

Fig. (3). Effect of GCV, PCV, GA, H\% on seed yield/plant.

ph: plant height $(\mathrm{cm})$, nb: number of branches/plant, df: days to maturity, dm: days to maturity, np: number of pods/plant, ns: number of seeds/plant, 100sw 100 - seed weight (g) and swp: seed yield/plant (g).

yield/plant, the number of branches/plant, seed weight/plant, the number of seeds/plant and the number of pods/plant indicating the importance of the additive gene effects, so, selection would be effective in early generations for these traits. High values of heritability accompanied with low genetic advance for plant height, 100-seed weight, days to flowering and days to maturity are indicative of non-additive gene effects. Therefore, limited scope for improvement of these traits is expected under the tested genotypes. The current conclusions are supported by Mehasen and Mohamed (2004), who confirmed that plant breeders can safely make their selection when they take in consideration high values of heritability and genetic advance.

The estimates of GCV and PCV values give the extent of variability existing for various traits, but do not give any information about the 
heritable portion of it. Therefore, estimates of heritability and genetic advance would give better idea about the possible gains of selection (Chavan et al., 1994).

\section{Conclusion}

Based on the results obtained in this study the following conclusions could be drawn:- Results from the present study indicate that cross 1 and cross 8 gave the highest seed yield per plant. Highly significant and positive associations were obtained between seed weight/plant and each of the number of seeds/plant and the number of pods/plant. The full model regression and stepwise regression analysis gave, R-square of 0.995 and $99.26 \%$ of the total variation exist in seed yield / plant trait. factor analysis classified the eight studied characters The hierarchical cluster analysis permitted the classification of the genotypes according to similarity groups. Large proportions of heritability coupled with high values of genetic advance (\% of mean) were recorded for the number of branches/plant, seeds yield/ plant, number of seeds and the number of pods/plant. The information from this study would be a valuable to Faba bean breeder for developing high yielding genotypes.

\section{REFERENCES}

Bastawisy M. H., Rahhal M. M. H., El-Garhy A. M., Raghed S. B., Darwish I.H. and Omran M. M. (2006). Evaluation of yield and yield components of newly developed Faba bean (Vicia faba L.) lines as affected by some foliar diseases. Annals Agric. Sci., Moshtohor, 44(4): 1497 - 1508.

Bond D.A., Lawes D.A., Hawtin G.C., Saxena M.C., and Stephens J.H. (1985). Faba bean (Vicia faba L.). In: Summer field RJ, Roberts EH (Eds) Grain Legume Crops, Collins, London, UK, pp. 199-265.

Burton G. W. (1951). Quantitative inheritance in pearl millet (Pennisetum gucum). Agron. J., 43: 409 - 417.

Cattell R.B., (1965). Factor analysis: an introduction to essentials. 1. The purpose and underlying models. Biometrics, 21: 190-215.

Chaieb N., Bouslama M. and Mars M. (2011). Growth and yield parameters variability among Faba bean (Vicia faba L.) Genotypes. J. Nat. Prod. Plant. Res., 1: 81-90.

Chavan V. W., Patil H.S. and Rasal P.N. (1994). Genetic variability correlation studies and their implications in selection of high yielding genotypes of chickpea. Madras Agric. J., 81:463-465

Comstok R. E. and Moll R. H. (1963). Genotype $\mathrm{X}$ environment interaction. Statistical Genetics and Plant Breeding, Syposuim, North Carolina Publication, USA, 982: pp:164-196.

Cowen N. M. and Frey K. J. (1987). Relationships between three measures of genetic distance and breeding methods in oat (Avena sativa L.)." Genome 29, 97 106.

Draper N.R. and Smith H. 1966. Applied Regression Analysis. Wiley, New York, 697pp.

Duc G. (1997). Faba bean (Vicia faba L.). Field Crop Res. 53: 99-109.

Duke J.A. (1981). In: Handbook of Legumes of World Economic Importance, Plenum Press, New York, USA, pp 199-265.

Eisen M.B., Spellman P.T., Brown P.O., Botstein D. (1998). Cluster analysis and display of genome-wide expression ilatteriis. Proc. Nat. Acad. Sci., USA, 95: (25) 14863-14868.

EL-Badawy M. E. M. (2006). The relative contribution of yield components by using specific statistical techniques in corn. Annals Agric. Sci., Moshtohor, 44(3): 899 $-909$.

Everitt B.S. (1993). In: Cluster Analysis. Wiley, New York, NY. USA, P: 253-265.

Fehr W.R. (1987). In: Principles of Cultivar Development. Vol. I.: Macmillan. Pub, New York, USA.

Golparvar A.R. (2012). Multivariate analysis and determination of the best indirect selection criteria to genetic improvement the biological nitrogen fixation ability in common bean genotypes (Phaseolus vulgaris L.). Genetika, 44 (2): 279 - 284.

Gomez K. A. and Gomez A. A. (1984). Statistical Procedures For Agricultural Research. $2^{\text {nd }}$ Ed. John Wiley \& Sons, New York, USA.

Hair J.R., Anderson R.E., Tatham R.L. and Black W.C. (1995). In: Multivariate Data A nalysis with Readings. $4^{\text {th }}$ edition, Prentice- Hall, Englewood Cliffs, NJ

Hakan U., Guler M. and Keskin S. (2003). A path coefficient analysis of some yield and yield components in Faba bean (Vicia faba L.) genotypes Pakistan Journal of boil. Sci. 6 (23):1951-1955. 
Hanson W. D. (1963). Heritability. St. Genet. And Pl, Breed. Syposuim, North Carolina Publication, USA, 982: 125 - 140.

Ihsanullah D., Sepetoglu H., Marwat K. B. and Geverek M. N. (2010). Nutrient removal, performance of growth and yield of Faba bean (Vicia faba L.) Pak. J. Bot., 42(5): 3477-3484.

Johnson H.F., Robinson H.F., Comstock R. E. (1955). Estimates of genetic and environmental variability in soybean. Agro. J. 47: 314- 318.

Kaiser H.F., (1958). The varimax criterion for analytic notation in factor analysis. Psychometricka, 23: 187-200

Kang M. S. (1994). In: Applied Quantitative Genetics. Kang publ. Baton Rouge, LA, USA.

Mathur S. C., P. K. Mathur and R. P. Chandola (1971). Genetic variability in (Cuminum cyminum L.). Indian J. Agric. Sci., 41:513- 515.

Mehasen S. A. S and Mohamed N. A. (2004). Factor analysis and genetical parameters on yield and its components of two varieties and a new promising line of Faba bean as affected by manganese and zink application, J. Appl. Sci,19 (11): 173-187.

Mojgan K., Golparvar A. R. and Shams M. (2013). Multivariate regression and path coefficient analysis of seed and oil yield in spring safflower (Carthamus tinctorius L.) cultivars. App. Sci. Reports. 4 (1): 184-186.

Nadal S., Suso M.J. and Moreno M.T (2003). Management of Vicia faba genetic resources changes associated to the selfing process in the major,equine and minor groups. Gen. Res. and Crop Evol. 50: 183192.

Nawar A.I., Al-Fraihat A.H., Khalil H.E.S. and El-Ela A.M.A. (2010). Response of Faba bean to tillage systems, different regimes of NPK fertilization and plant interspacing. Int. J. Agric. Biol., 12: 606610

Peyman S. and Aminpana H. (2014). A study on the genetic variation in some of Faba bean genotypes using multivariate statistical techniques. Trop. Agric. (Trinidad), 91 (2):87-97.

Polignano G.B., Uggenti P. and Perrino P. (1989). Pattern analysis and genotypic $x$ enviromnemnt interactions in Faba bean (Vicia faba L.) populations. Euphytica, 40: 31-41.

Salem S. A. (2011). Genetic Behavior of Some Selected Faba Bean Genotypes J. Nat. Prod. Plant Res., 1 (2): 81-90.

Sarparast R., Sheikh F. and Sowghi H.A. (2011). Investigation of genotype and environment interaction and cluster analysis for seed yield in different lines of Faba bean (Vicia faba L.). Iranian J. Puls. Res, 2 (1): 99-106.

Sieler G.I. and Stafford R. E. (1985). Factor analysis of components in guar. Crop Sci., 25: $905-908$.

Snedecor G.W. and Cochran W. G. (1989). In: Statistical Methods, $8^{\text {th }}$ Ed. Iowa State Univ. Press, Ames, Iowa, USA.

Sokal R. R . and Michener C. D. (1958). A statistical method for evaluating systematic relationships. Univ. Kansas Scie. Bull., 28: 1409 - 1438.

Tafere M., Dessalegn T. and gzaw Y.i. (2013). Genetic variability, heritability and correlation in some Faba bean genotypes (Vicia faba L.) grown in Northwestern Ethiopia. Int. J. Gene. \& Mol. Biology. 5 (1): 8-12.

Talal A. and Shtaya M. J. Y. (2013). Phenotypic characterization of Faba bean (Vicia faba L.) landraces grown in Palestine. J. Agri. Scie., 5(2):110-117.

Verma G. and K. P. Singh (1971). Selection based on multiple characters in bamyard millet (Echinochloe aestivum L.) Madras J. Agric., 58: 194 - 198.

Wani S.P., Mc Gill W.B., Haugen- Kozyra K. L., Robertson J. A. and Thurston J.J. (1994). Improved soil quality and barley yields with faba beans, manure, forages and crop rotation on a Gray Luvisol Canadian Journal of Soil Science, 74 (1): 75-84. 


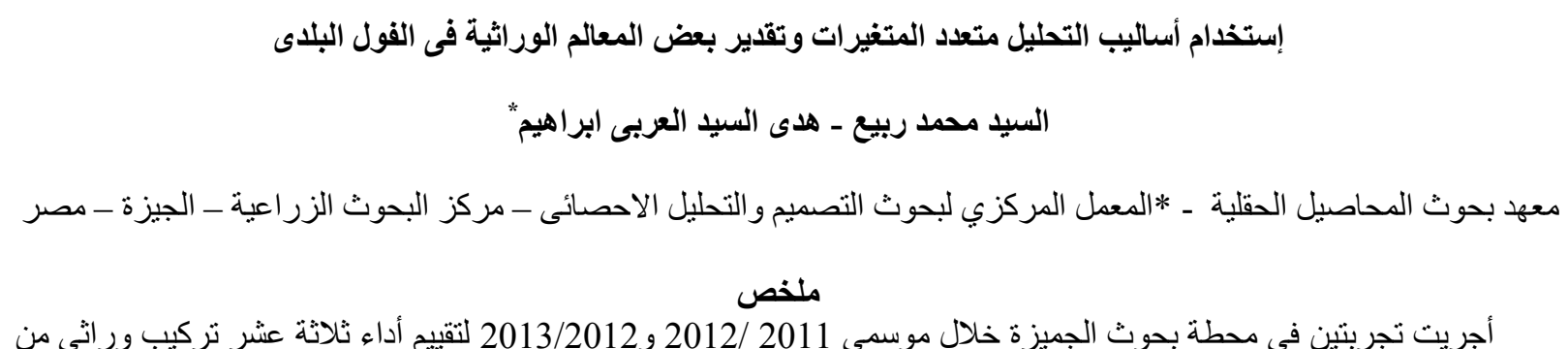

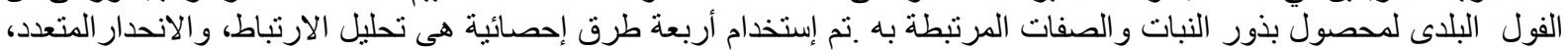

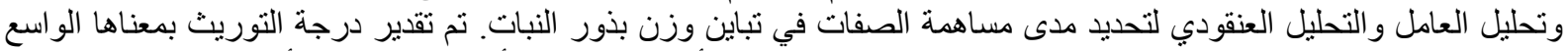

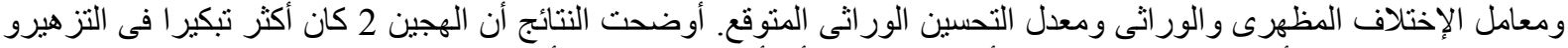

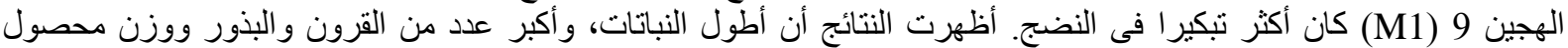

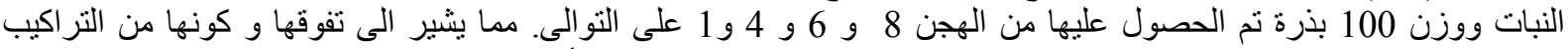

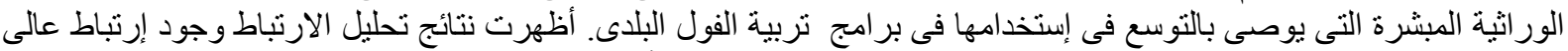

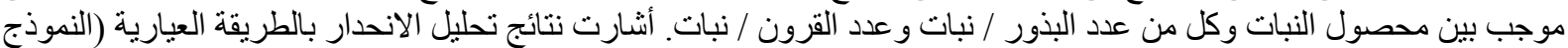

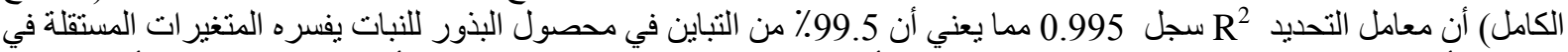

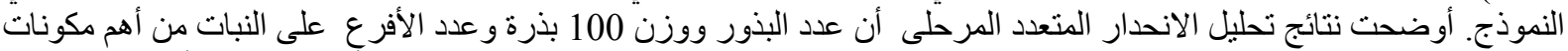

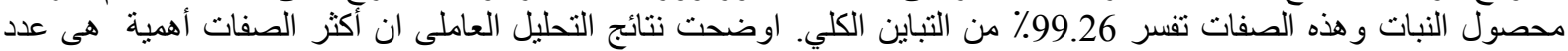

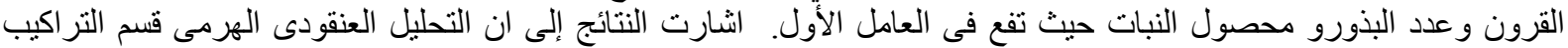

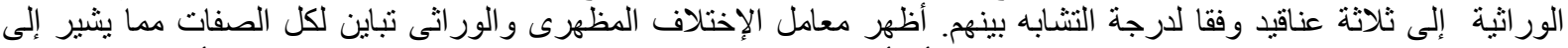

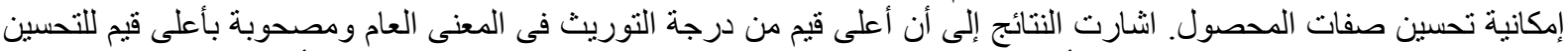

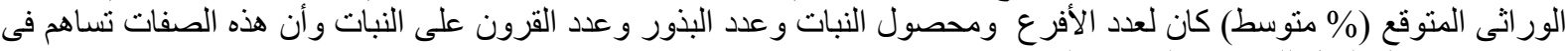

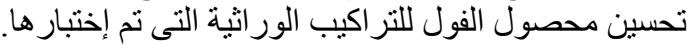

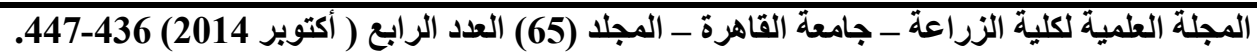

